\title{
Erythropoietin improves skin wound healing and activates the TGF- $\beta$ signaling pathway
}

\author{
Nikolai Siebert*, Weiguo Xu*, Eberhard Grambow, Dietmar Zechner and Brigitte Vollmar
}

We could recently report that erythropoietin (EPO) accelerates skin wound healing in mice. Now, we provide insight into the molecular mechanisms of this non-hematopoietic property of EPO analyzing the transforming growth factor (TGF)- $\beta$ signaling pathway. EPO receptor was found expressed in both non-wounded and wounded skin tissue as well as in fibroblasts and keratinocytes. In saline-treated control animals, wounds exhibited a significant upregulation of TGF- $\beta 1$ and of $\alpha$-smooth muscle actin ( $\alpha$-SMA) compared with non-wounded skin. EPO treatment accelerated wound epithelialization and induced mRNA expression of TGF- $\beta 1$ and $\alpha$-SMA. In addition, EPO significantly enhanced phosphorylation of Smad2 and Smad3 in fibroblasts and also elevated phosphorylation of Smad3 in wound tissue. Blockade of TGF- $\beta$ using a neutralizing anti-TGF- $\beta$ antibody attenuated EPO-induced acceleration of wound epithelialization in vivo and markedly reversed EPO effects on mRNA expression of TGF- $\beta 1$ and $\alpha$-SMA. In conclusion, EPO caused activation of the Smad-dependent TGF- $\beta$ signaling pathway, enhanced differentiation of myofibroblasts, and accelerated skin wound closure.

Laboratory Investigation (2011) 91, 1753-1765; doi:10.1038/labinvest.2011.125; published online 5 September 2011

KEYWORDS: epithelialization; extracellular matrix; Smad proteins; skin wound repair

Erythropoietin (EPO) is a hematopoietic factor regulating proliferation and differentiation of erythroid precursor cells. ${ }^{1,2}$ In the hematopoietic system, this process is mediated by its specific cell surface receptor (EPOR). ${ }^{2,3}$ The binding of EPO to its receptor results in induction of expression of different target genes leading to inhibition of apoptosis. ${ }^{2}$ In recent years, it has been shown that EPOR is also expressed by non-erythroid tissues. These studies have been associated with the discovery of new biological functions of endogenous EPO signaling and the ability of exogenous EPO to modulate cellular responses upon diverse types of injury. ${ }^{2,4-6}$

EPO has been shown to exert a prohealing effect in cutaneous tissue, which was associated with the ability to stimulate blood vessel growth during the formation of granulation tissue. ${ }^{7}$ Confirming and extending this information, we could demonstrate in a murine model of skin wound healing that EPO accelerates maturation of newly formed microvessels at the wound site, enhances epithelialization of the wound area and shortens the inflammatory phase with faster resolution of the early granulation tissue. ${ }^{8}$ Most recently, EPO was shown to promote wound repair in rats even under diabetic conditions. ${ }^{9}$
Upon skin injury, a series of events take place aiming at the reconstruction of the wounded tissue. Wound repair is one of the most complex biological processes with multiple pathways, which are immediately activated after injury, including inflammation, granulation tissue formation, and tissue remodeling. This complex process is executed and regulated by an equally complex signaling network involving numerous growth factors, cytokines, and chemokines. ${ }^{10,11}$ Among them, the transforming growth factor (TGF) $\beta$ has emerged as the major modulator of wound healing by regulating cell proliferation of fibroblasts, stimulation of extracellular matrix deposition, and angiogenesis. ${ }^{10,12}$ Upon binding of TGF- $\beta$ to heterodimeric receptor complexes, the latter become autophosphorylated and activate the downstream signaling molecules belonging to the Smad family of transcription factors. ${ }^{10,11}$ Activated TGF- $\beta$ receptors induce phosphorylation of Smad2 and -3 , which form a heterooligomeric complex with the common mediator Smad4. ${ }^{13-15}$ These complexes are translocated into the nucleus and regulate ligand-induced gene transcription. The process of signal transduction after activation of TGF- $\beta$ receptors is further regulated by Smad7, functioning as an intracellular 
antagonist of the pathway. ${ }^{16}$ Smad7 associates with activated TGF- $\beta$ receptors and hinders the activation of Smad 2 and -3 by preventing their phosphorylation by activated TGF- $\beta$ receptors. ${ }^{16}$

Taking into account the pivotal role of TGF- $\beta$ in wound healing, the present study analyzed whether salutary effects of EPO treatment in skin wounds involve the TGF- $\beta$ signaling pathway. First, we examined EPOR expression in skin tissue, on fibroblasts, and on keratinocytes. Second, we studied whether EPO treatment of skin wounds in mice activates the TGF- $\beta$ signaling pathway and affects the expression of TGF- $\beta 1$ and of the TGF- $\beta$ target gene $\alpha$-smooth muscle actin $(\alpha$-SMA). Finally, we evaluated if EPO accelerates wound healing in a TGF- $\beta$-dependent manner by using an anti-TGF$\beta$ antibody in EPO- and saline-treated mice.

\section{MATERIALS AND METHODS Animal Model}

All procedures were approved by the local animal care and use committee and were performed in accordance with the German legislation on protection of animals and the NIH Guide for the Care and Use of Laboratory Animals (DHEW Publication No. (NIH) 86-23, Revised 1985). A total of 66 male homozygous SKH1- $h r$ hairless mice (12-16 weeks old, 25-35 g) were used for the study. The animals were housed in standard laboratories with a 12-h light-dark cycle and had free ad libitum access to standard laboratory food and water.

For the dorsal skin fold chamber preparation, mice were anesthetized by intraperitoneal (i.p.) application of ketamine ( $90 \mathrm{mg} / \mathrm{kg}$ bw i.p.; Bela-Pharm, Vechta, Germany) and xylazine $(25 \mathrm{mg} / \mathrm{kg}$ bw i.p.; Bayer Health Care, Leverkusen, Germany). To implant the chamber $(n=66)$, the dorsal skin fold was sandwiched between two symmetric titanium frames. The creation of a full dermal thickness wound $(n=57)$ was achieved after marking the area with a standardized circular ink stamp ( $3 \mathrm{~mm}$ in diameter). In all, $7 \mathrm{~mm}^{2}$ of skin was wounded only at one side of the skin fold by removing epidermis and dermis as well as the subcutis and the panniculus carnosus. To prevent desiccation, the wound area was covered with a removable glass coverslip incorporated in one of the titanium frames. Animals tolerated the chamber well and showed no signs of discomfort or changes in sleeping and feeding habits during the whole observation period.

In line with our previous experimental protocol, ${ }^{8}$ animals received either a single i.p. injection of EPO (Epoetin- $\alpha$ of ovarian cells of the Chinese hamster cell line CHO-K1 (Janssen-Gilag, Neuss, Germany); 5000 U/kg bw i.p.; EPO; $n=18)$ at the day of wounding or an equivalent volume of physiological saline $(\mathrm{NaCl} 0.9 \% ; 1 \mathrm{ml} / \mathrm{kg}$ bw i.p.; control; $n=17)$. Additional animals received a single i.p. injection of EPO (5000 U/kg bw i.p.) and a pan-specific anti-TGF- $\beta$ antibody (R\&D Systems GmbH, Wiesbaden-Nordenstadt, Germany; $1 \mathrm{mg} / \mathrm{kg}$ bw i.p.) at the day of wounding. Application of the TGF- $\beta$ neutralizing antibody ( $1 \mathrm{mg} / \mathrm{kg}$ bw i.p.) was repeated daily until day $12(\mathrm{EPO}+$ anti-TGF- $\beta ; n=11)$.
An additional group of saline-treated animals received the pan-specific anti-TGF- $\beta$ antibody, as described above $(1 \mathrm{mg} / \mathrm{kg}$ bw i.p. for 12 days; $\mathrm{NaCl}+$ anti-TGF- $\beta ; n=11)$.

On days 3, 6, 9, and 12 after wounding, analysis of wound epithelialization was performed under a stereomicroscope using planimetric techniques (IC-A; Leica Microsystems $\mathrm{GmbH}$, Wetzlar, Germany). Wound closure was considered complete when the entire surface area was covered with epithelial tissue. The analysis of epithelialization was done in a blinded manner by two independent observers showing minimal inter-individual variation underlining the reliability of the analysis. To consider influences of the chamber implantation, an additional group of animals underwent implantation of the dorsal skin fold chamber, but did not undergo wounding (sham; $n=9)$. At the end of the observational time period (day 12), skin tissue samples were taken for subsequent laboratory analysis.

\section{Isolation of Primary Skin Fibroblasts}

Skin biopsy material was obtained from the back of SKH1-hr hairless mice $(n=3)$, cut into fragments of $1 \mathrm{~mm}^{3}$ and placed in culture flasks with appropriate medium (see below). After 80-90\% confluence, primary skin fibroblasts were twice passaged before being used for further experiments.

\section{Cell Culture Experiments}

To study the phosphorylation of Smad2 and Smad3 proteins as well as to examine the expression of EPOR, murine keratinocytes (MSC-P5 cell line), fibroblasts (L929 cell line), or murine primary skin fibroblasts were seeded onto either culture flasks $\left(5 \times 10^{5}\right.$ cells per flask (TPP AG, Trasadingen, Switzerland) for gene expression analysis or chamber slides (Nalge Nunc International, Rochester, NY, USA) for immunohistochemical analysis. Keratinocyte-specific expression pattern of the MSC-P5 cell line was verified by immunohistochemistry for the positive staining of cytokeratin 16 (rabbit anti-cytokeratin 16 antibody, ab76416, Abcam, Cambridge, UK). L929 and MSC-P5 cell lines were cultured in Dulbecco's modified Eagle's medium (DMEM low-glucose), 10\% FCS and 1\% penicillin/streptomycin for $48 \mathrm{~h}$. Primary fibroblasts were cultured in DMEM low-glucose, $20 \%$ FCS, and $1 \%$ penicillin/streptomycin. For immunohistochemical demonstration of EPOR, cells were fixed and further processed as described below.

For gene expression analysis or evaluation of phosphorylation of Smad2 and Smad3, cells were exposed for additional $24 \mathrm{~h}$ to medium supplemented with EPO (EPO; 50 $\mathrm{U} / \mathrm{ml}$ ). All experiments were performed in triplicate. To evaluate the effect of EPO on cell migration, $2 \times 10^{5}$ L929 fibroblasts were seeded onto $35 \mathrm{~mm}$ dishes containing a cell culture insert (ibidi, Munich, Germany). The cells were grown to confluency. After removal of the cell culture insert, which created a $500-\mu \mathrm{m}$ gap between the cell patches, the cells were treated with medium containing 10\% FCS and 
$50 \mathrm{U} / \mathrm{ml}$ EPO (Janssen-Gilag) or $10 \mathrm{ng} / \mathrm{ml}$ TGF- $\beta 1$ (SigmaAldrich, Saint Louis, MO, USA).

\section{RNA Extraction}

Total RNA from non-wounded skin, skin wound tissue, and cultured cells was isolated using a RNeasy Mini Kit (Qiagen, Germany) according to the manufacturer's instructions. For stabilization of skin tissue RNA, tissue samples were preincubated with RNA stabilization buffer (Qiagen) for $24 \mathrm{~h}$ at $4^{\circ} \mathrm{C}$. Total RNA was eluted in nuclease-free water, quantified spectrophotometrically at $260 \mathrm{~nm}$, and kept at $-80^{\circ} \mathrm{C}$ until use.

\section{Real-Time PCR}

First-strand CDNA was synthesized by reverse transcription of $2 \mu \mathrm{g}$ of total RNA using oligo(dT) 18 primer (Biolabs, Frankfurt am Main, Germany) and Superscript II RNaseHReverse Transcriptase (Invitrogen, Karlsruhe, Germany) in the presence of dNTP's, $5 \times$ first-strand buffer and dithiothreitol at $72^{\circ} \mathrm{C}$ for $10 \mathrm{~min}$ and $42^{\circ} \mathrm{C}$ for $60 \mathrm{~min}$. The reverse transcriptase was inactivated by $95^{\circ} \mathrm{C}$ for $5 \mathrm{~min}$. Expression levels of $\alpha$-SMA, TGF- $\beta 1$, TIMP-1, Smad $2,-3,-4$, and -7 mRNA were quantified using LightCycler System 1.5 (Roche, Mannheim, Germany) relative to control samples and normalized to the expression of the reference gene GAPDH. For our approach we used SYBR Green I (Roche). The sequences of primers are detailed in Table 1. Primers were designed spanning introns to exclude amplification of contaminating genomic DNA. The real-time PCR program included a 10-min denaturation step followed by $40-50$ amplification cycles. After each LightCycler run, a melting curve analysis was performed to analyze the products of the PCR. For the quantification of mRNA, all samples were analyzed in duplicates. Probes without cDNA template (non-template control (NTC) served as negative control. In addition, results of real-time PCR were reproduced by repeating each experiment and stopping the PCR at the logarithmic phase. PCR products were run on a $1 \%$ agarose gel to compare the intensity of each PCR product.

\section{Western Blot Analysis}

For western blot analysis of EPOR and of phosphorylation of Smad2 and Smad3, MSC-P5 keratinocytes and fibroblasts $\left(5 \times 10^{5}\right)$ were collected, washed in cold PBS $\left(4^{\circ} \mathrm{C}\right)$, homogenized in cold lysis buffer $(1 \mathrm{M}$ Tris $\mathrm{pH} 7.5,5 \mathrm{M} \mathrm{NaCl}$, $250 \mathrm{~mm}$ EDTA, $10 \%$ Triton-X 100, 4\% $\mathrm{NaN}_{3}, 100 \mathrm{~mm}$ PMSF), and phosphatase inhibitor mixture (PhosSTOP; Roche), incubated for $30 \mathrm{~min}$ on ice and centrifuged for $15 \mathrm{~min}$ at $10000 \mathrm{~g}$. Protein concentrations were determined using the BCA protein assay (Pierce, Rockford, IL, USA) with bovine serum albumin as standard. In all, $20 \mu \mathrm{g}$ of whole protein extracts were electrophoresed in sodium dodecyl sulfate polyacrylamide gels (12\% SDS-PAGE) and transferred onto polyvinyldifluoride membranes (Immobilon-P transfer membrane; Millipore, Billerica, MA, USA). After blockade of
Table 1 The sequences of primers used for RT-PCR analysis

\begin{tabular}{|c|c|c|c|}
\hline Gene & Primer & Sequence & $\begin{array}{c}\text { Product } \\
\text { size }\end{array}$ \\
\hline \multirow[t]{2}{*}{$E P O R$} & Forward & 5'-CCTGGACCCTCTCATCTTGA-3' & $219 b p$ \\
\hline & Reverse & $5^{\prime}$-CCACCACAGACAACCATCAC-3' & \\
\hline \multirow[t]{2}{*}{ TGF- $\beta 1$} & Forward & 5'-CCAGATCCTCTCCAAACTAA-3' & 344 bp \\
\hline & Reverse & 5'-GCTCCACAGTTGACTTGAAT-3' & \\
\hline \multirow[t]{2}{*}{$\alpha-S M A$} & Forward & 5'-ACTACTGCCGAGCGTGAGAT-3' & 452 bp \\
\hline & Reverse & 5'-AAGGTAGACAGCGAAGCCAG-3' & \\
\hline \multirow[t]{2}{*}{ TIMP-1 } & Forward & $5^{\prime}$-GCAGTGAAGAGTTCTCATC-3' & $312 b p$ \\
\hline & Reverse & 5'-TCATCGGGCCCCAAGGGATCT-3' & \\
\hline \multirow[t]{2}{*}{ Smad2 } & Forward & 5'-CTGGCTCAGTCTGTCAACCA-3' & $108 \mathrm{bp}$ \\
\hline & Reverse & 5'-CTGCCTCCGATATTCTGCTC-3' & \\
\hline \multirow[t]{2}{*}{ Smad3 } & Forward & 5'-TGTGCGGCTCTACTACATCG-3' & $171 b p$ \\
\hline & Reverse & 5'-GCAGCAAATTCCTGGTTGTT-3' & \\
\hline \multirow[t]{2}{*}{ Smad4 } & Forward & 5'-GTGACTGTGGATGGCTATGTGG-3' & $89 \mathrm{bp}$ \\
\hline & Reverse & 5'-GCAACCTCGCTCTCTCAATCG-3' & \\
\hline \multirow[t]{2}{*}{ Smad7 } & Forward & 5'-GCATTCCTCGGAAGTCAAGA-3' & $260 \mathrm{bp}$ \\
\hline & Reverse & 5'-CAGGCTCCAGAAGAAGTTGG-3' & \\
\hline \multirow[t]{2}{*}{ GAPDH } & Forward & 5'-AACGACCCCTTCATTGAC-3' & $191 \mathrm{bp}$ \\
\hline & Reverse & $5^{\prime}$-TCCACGACATACTCAGCAC-3' & \\
\hline
\end{tabular}

Specificity of primers was evaluated by analysis of the product melting curve and by gel-electrophoreses of the product. Only one product of the appropriate size was observed.

non-specific binding sites, membranes were incubated for $2 \mathrm{~h}$ at room temperature with rabbit polyclonal anti-EPOR (1:200; Santa Cruz Biotechnology, Europe), rabbit polyclonal anti-phospho-Smad2 (1:1000; Cell Signalling, Frankfurt am Main, Germany) and mouse monoclonal anti-Smad2 (1:2000; Cell Signalling) or with rabbit monoclonal anti-phospho-Smad3 (1:1000; Cell Signalling) and rabbit monoclonal anti-Smad3 (1:2000; Cell Signalling). Peroxidase-conjugated goat anti-rabbit or anti-mouse $\mathrm{IgG}$ antibodies were used as secondary antibodies (1:5000; SigmaAldrich). Antigens were revealed using a chemiluminescence assay (ECL plus; Amersham Pharmacia Biotech, Freiburg, Germany) and densitometrically semi-quantified (TotalLab, Nonlinear Dynamics, New Castle upon Tyne, UK). Experiments were repeated at least three times. EPOR expression was evaluated in relation to $\beta$-actin expression, whereas Smad activation was evaluated by normalizing the signal intensity of phosphorylated Smad2 or Smad3 to the total amount of the respective Smad protein.

\section{Histology and Immunohistochemistry}

The titanium frames were explanted on day 3 or day 12 and the sandwiched skin was fixed in $4 \%$ phosphate-buffered 
formalin for 2-3 days, embedded in paraffin, $4 \mu \mathrm{m}$ sections were serially cut and stained with hematoxylin-eosin for assessment of routine histology. For immunohistochemical demonstration of EPOR and Smad3 phosphorylation, skin tissue sections on poly-L-lysine-coated glass slides were treated by microwave for antigen unmasking. Tissue sections or fixed cells were then incubated with rabbit polyclonal anti-EPOR antibody (1:500; Santa Cruz Biotechnology) or rabbit anti-phospho-Smad3 antibody (1:200; C25A9, Cell Signalling) for $18 \mathrm{~h}$ at $4{ }^{\circ} \mathrm{C}$. After application of horseradish peroxidase-conjugated secondary antibodies (LSAB + SystemsHRP; Dako, Germany) and 3-amino-9-ethylcarbazole as chromogen (Dako), samples were counterstained with hemalaun and examined by light microscopy (Axioskop 40, Zeiss, Göttingen, Germany).

\section{Statistical Analysis}

After testing for normality and equal variance across groups, differences were assessed using one-way ANOVA test, followed by the appropriate post hoc pairwise comparison tests. A $P$-level of $<0.05$ was considered significant. All data are given as mean values \pm s.d. Analysis was performed using the software package SigmaStat (Jandel, San Rafael, CA, USA).

\section{RESULTS \\ EPO-Accelerated Wound Epithelialization Involves TGF- $\beta$}

The initial size of the wound was comparable in all four groups and averaged $6.4 \pm 1.1 \mathrm{~mm}^{2}$. In the control group, planimetric analysis showed a continuous epithelialization with $6 \pm 3 \%$ wound coverage at day 3 and $43 \pm 10 \%$ at day 9 (Figure 1) and almost complete wound closure (94 $\pm 9 \%$ ) at day 12. EPO induced a moderate, but significant acceleration of wound epithelialization with $10 \pm 2 \%$ wound closure at day 3 and $76 \pm 17 \%$ at day 9 , resulting in complete wound closure $(100 \pm 0 \%)$ at day 12 (Figure 1 ). TGF- $\beta$ blockade using a neutralizing anti-TGF- $\beta$ antibody reversed the effect of EPO on wound epithelialization (Figure 1). This effect is small, but significant on day 3 , day 6 , and day 9 after wounding. In saline-treated animals, being exposed to the anti-TGF- $\beta$ antibody, a slower wound epithelialization was observed, although differences were minimal and not statistically significant (Figure 1).

\section{EPOR Is Expressed in Skin Tissue, Cultured Fibroblasts, and Keratinocytes}

In order to evaluate if EPO could act locally, we analyzed EPOR expression by immunohistochemistry of skin samples
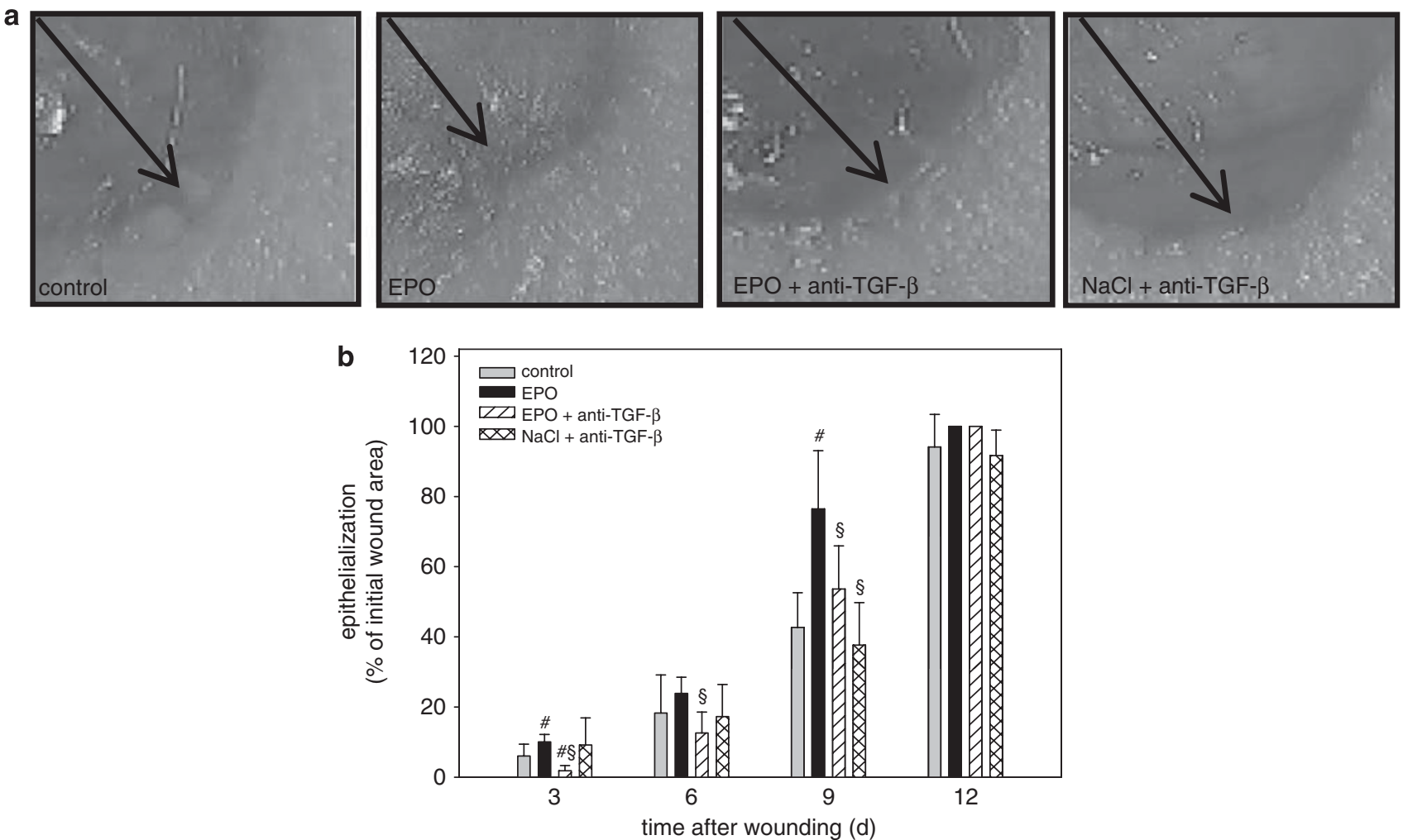

Figure 1 Representative photomacroscopic images of wounds (a, day 9 after wounding) and planimetric analysis of wound epithelialization (b)

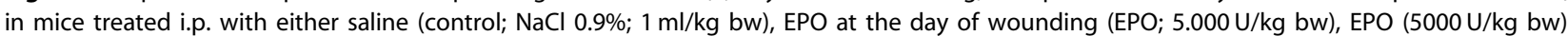
and a pan-specific anti-TGF- $\beta$ antibody ( $1 \mathrm{mg} / \mathrm{kg} \mathrm{bw})$, or $\mathrm{NaCl} 0.9 \%$ and a pan-specific anti-TGF- $\beta$ ( $1 \mathrm{mg} / \mathrm{kg}$ bw) at the day of wounding. Application of the anti-TGF- $\beta$ antibody was repeated daily until day 12 (EPO + anti-TGF- $\beta ; \mathrm{NaCl}+$ anti-TGF- $\beta$ ). Arrows in (a) depict the non-epithelialized area of the wound. Values are given as mean values \pm s.d. ANOVA, followed by appropriate post hoc comparison test; ${ }^{\#} P<0.05$ vs control; ${ }^{\S} P<0.05$ vs EPO. 
(Figures 2b-f). Strong immunoreactivity for EPOR was found in epithelial layer (Figure 2d), hair follicle epithelium (Figure 2e), and dermal layer of skin tissue (Figure 2f).

To characterize which cell type of the dermal layer expresses EPOR, we cultured mouse keratinocytes (MSC-P5) and primary mouse fibroblasts on glass slides. Positive staining for EPOR was observed in both cell types (Figure 3a). Furthermore, real-time PCR analysis (primers used in all real-time PCR experiments are detailed in Table 1) revealed EPOR mRNA transcripts in both cell types (Figure 3b). Consistent with immunohistochemical and realtime PCR data, EPOR protein expression was detected in MSC-P5 keratinocytes and in primary fibroblasts by western blot analysis (Figure 3c).
We also analyzed EPOR expression in non-wounded and wounded skin tissue (day 12) and observed positive immunoreactivity for EPOR in respective tissue specimen (Figures 4a and b). Moreover, we examined whether EPO application changed EPOR mRNA expression in skin tissue and found no statistically significant difference of EPOR mRNA expression in wounds of control animals compared with non-wounded skin (Figure 4c). There was also no relevant change of EPOR mRNA expression in wounds after either EPO, EPO + anti-TGF- $\beta$ antibody treatment, or $\mathrm{NaCl}+$ anti-TGF- $\beta$ antibody treatment (Figure $4 \mathrm{c}$ ).

\section{EPO and TGF- $\beta 1$ Stimulate Migration of Fibroblasts In Vitro} In order to compare the effects of EPO with TGF- $\beta 1$ on the migration of fibroblasts, we evaluated migration of L929
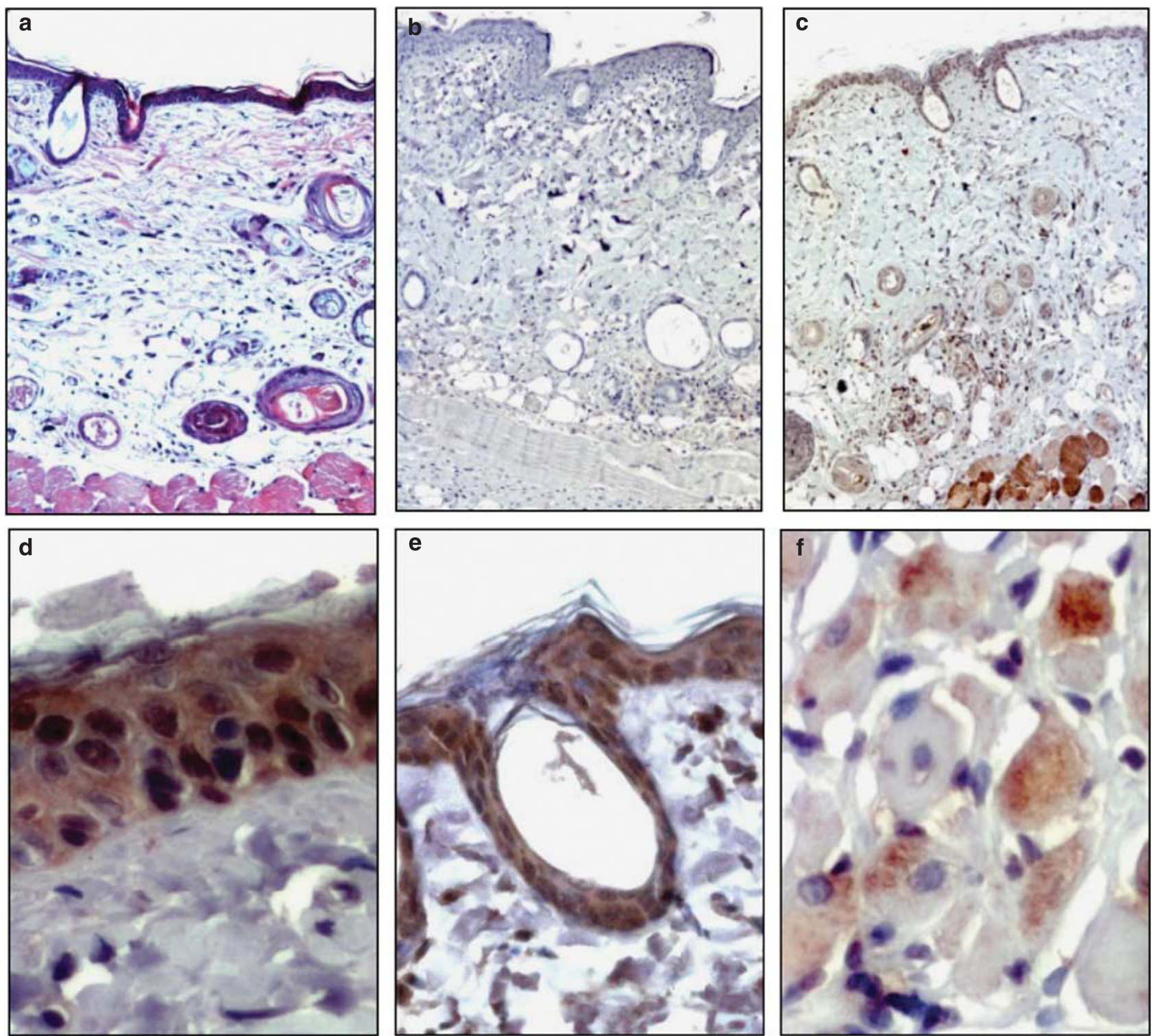

Figure 2 Representative histological H\&E-stained section (a) and immunohistochemical images of EPOR expression (c-f) in non-wounded skin of the mouse dorsal skin fold chamber (sham group). (b) Negative control of EPOR immunohistochemistry. Magnification $\times 20$ (a-c) and $\times 40$ (d-f). 
a
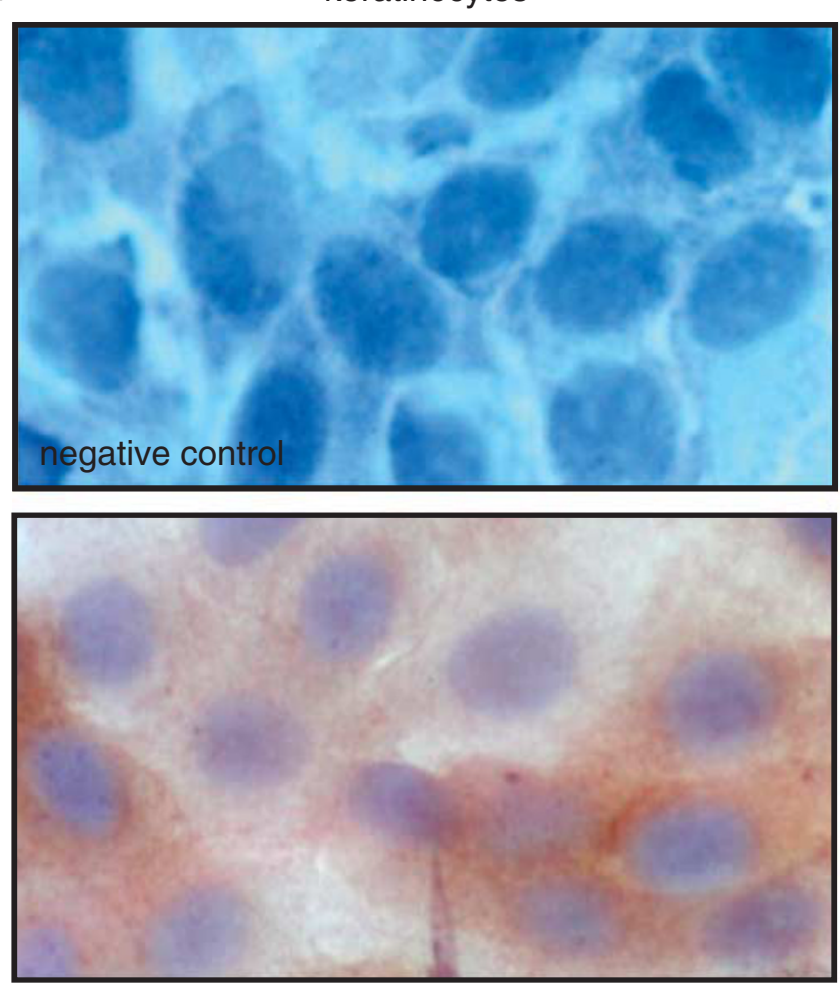

fibroblasts
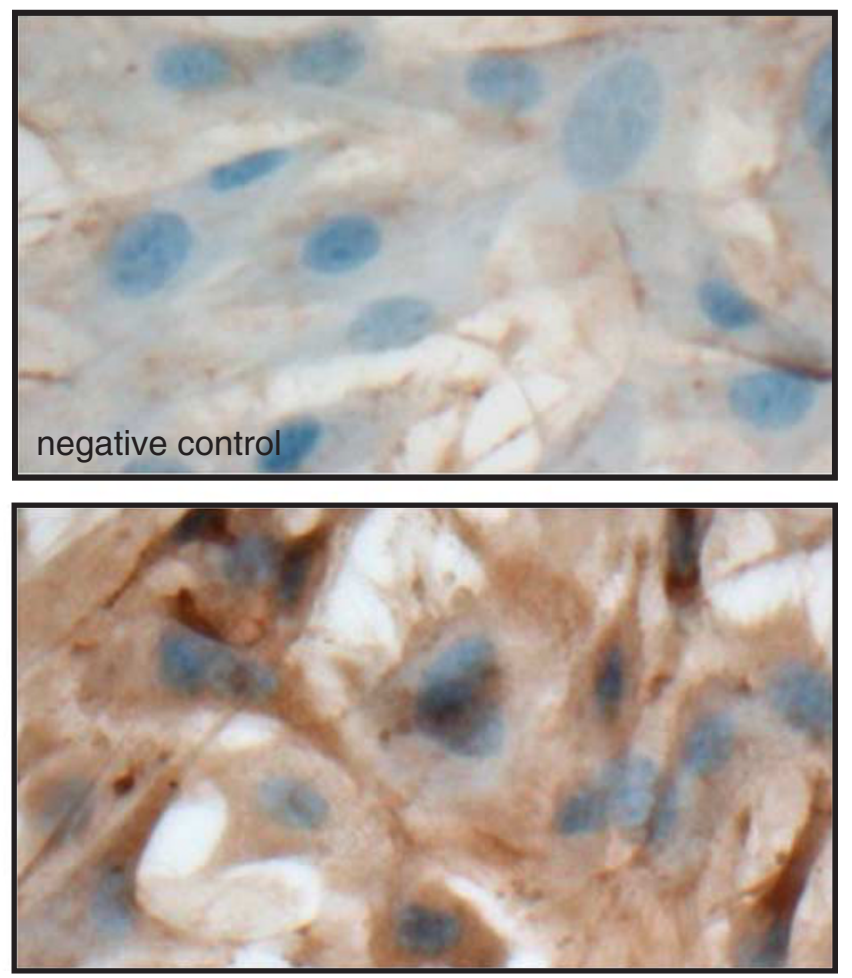

fibroblasts

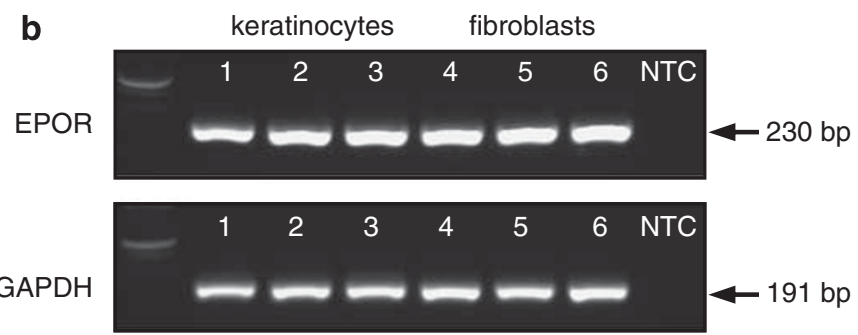

\begin{tabular}{|c|c|c|c|c|c|c|}
\hline \multirow[t]{2}{*}{ C } & \multicolumn{3}{|c|}{ keratinocytes } & \multicolumn{3}{|c|}{ fibroblasts } \\
\hline & 1 & 2 & 3 & 4 & 5 & 6 \\
\hline EPOR & 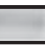 & +2 & +2 & 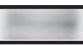 & 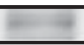 & 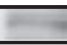 \\
\hline & 1 & 2 & 3 & 4 & 5 & 6 \\
\hline
\end{tabular}

Figure 3 Immunohistochemistry (a, magnification $\times 40)$, real-time PCR $(\mathbf{b})$, and western blot $(\mathbf{c})$ analysis of EPOR expression in murine keratinocytes (MSC-P5) and murine primary fibroblasts. GAPDH and $\beta$-actin served as internal control for real-time PCR and western blot analysis, respectively (the data represent three independent experiments). NTC, non-template control.

fibroblasts into a $500-\mu \mathrm{m}$ wide gap within a confluent cell monolayer. Non-treated cells covered $66.4 \pm 5.9 \%$ of the gap area within $36 \mathrm{~h}$, whereas, TGF- $\beta 1$-stimulated fibroblasts covered $97.5 \pm 3.1 \%$ and EPO-treated fibroblasts covered $100 \pm 0 \%$ of the gap area within $36 \mathrm{~h}$ (Figure 5). Thus, both EPO and TGF- $\beta 1$ significantly stimulated fibroblast migration.

\section{EPO Increases mRNA Expression of TGF- $\beta 1$ and $\alpha$-SMA in Skin Wounds}

In control animals, skin wounding resulted in an $\sim 7$-fold increased level of TGF- $\beta 1$ mRNA transcripts (Figure 6a).
The rise of TGF- $\beta 1$ mRNA was further doubled upon wounding in EPO-treated animals (Figure 6a) and was found completely reversed upon TGF- $\beta$ blockade (Figure 5a). Interestingly, TGF- $\beta$ blockade alone did not change the mRNA expression compared with controls (Figure 6a).

Wound repair and wound maturation are characterized by a phenotypic switch of fibroblasts towards myofibroblasts as well as the continued synthesis, degradation, and maturation of collagen. We studied mRNA expression of $\alpha$-SMA, which is known to be a marker of myofibroblast development. ${ }^{17}$ Twelve days after wounding, EPO-treated animals revealed an 
a

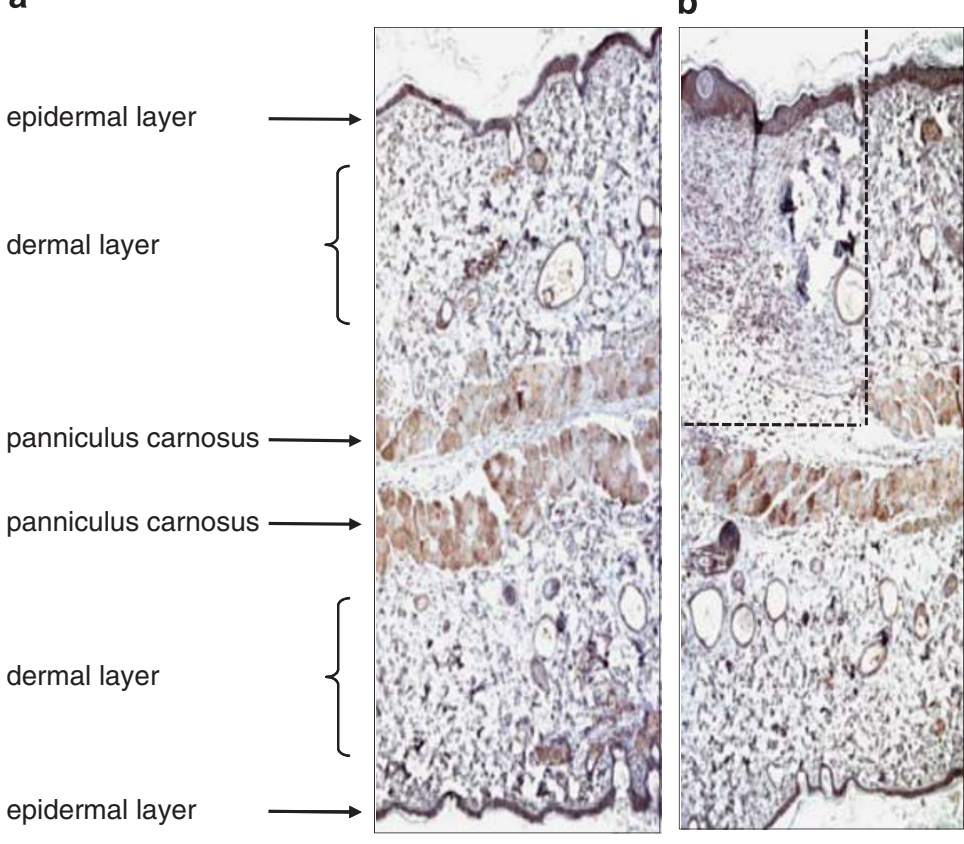

C
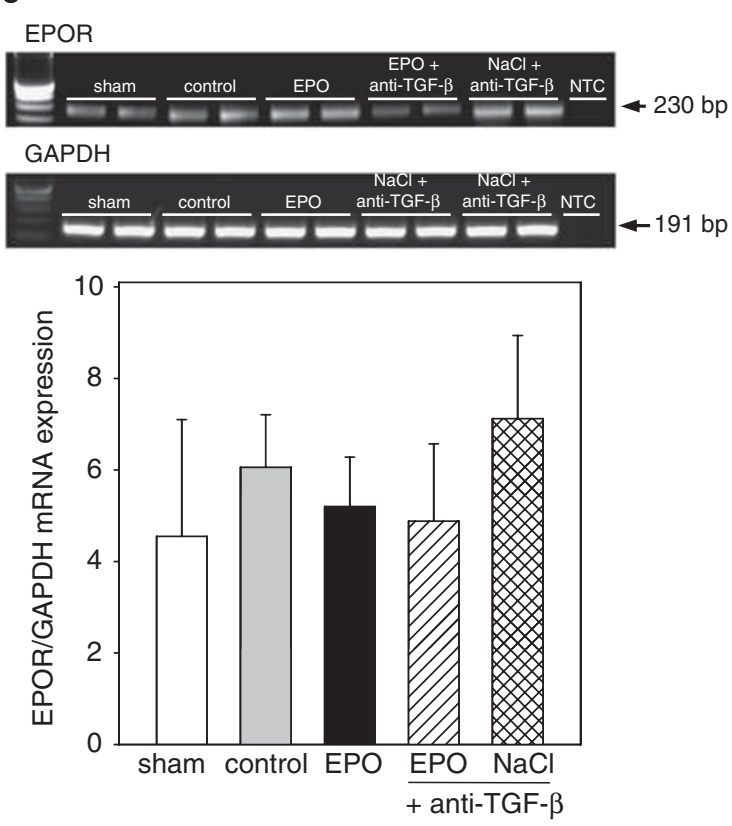

Figure 4 Representative EPOR immunohistochemistry in sections of the mouse dorsal skin fold chamber (a, sham group; (b), control group at day 12 postwounding; $\times 6.3$ magnification) as well as quantification of real-time PCR (c) and a representative picture of the real-time PCR stopped at logarithmic phase of the PCR (c). Real-time PCR was performed on reverse-transcribed mRNA from skin tissue at day 12 post-wounding (control, EPO, EPO + anti-TGF- $\beta$, and $\mathrm{NaCl}+$ anti-TGF- $\beta$ group) or non-wounded skin (sham group). Dashed line indicates initial wound edges (b). Animals were treated i.p. with either saline (control; $\mathrm{NaCl} 0.9 \% ; 1 \mathrm{ml} / \mathrm{kg} \mathrm{bw})$, EPO at the day of wounding (EPO; $5.000 \mathrm{U} / \mathrm{kg} \mathrm{bw})$, EPO (5000 U/kg bw) and a pan-specific anti-TGF- $\beta$ antibody $(1 \mathrm{mg} / \mathrm{kg} \mathrm{bw})$, or $\mathrm{NaCl} 0.9 \%$ and a pan-specific anti-TGF- $\beta(1 \mathrm{mg} / \mathrm{kg}$ bw) at the day of wounding. Application of the anti-TGF- $\beta$ antibody (1 mg/kg bw i.p.) was repeated daily until day 12 (EPO + anti-TGF- $\beta$; NaCl + anti-TGF- $\beta$ ). GAPDH served as reference gene for correcting the quantification of all target genes. Values are given as mean values \pm s.d. NTC, non-template control (negative control).

$\sim 6$-fold higher expression level of $\alpha$-SMA mRNA in skin tissue compared with non-wounded skin (Figure 6b), while in skin wounds of controls, $\alpha$-SMA mRNA expression level exceeded that of the sham group only threefold (sham: $2.6 \pm 1.8$; control: $8.6 \pm 4.5$; EPO: $15.2 \pm 8.1$ ). Notably, TGF- $\beta$ blockade in EPO-treated animals reduced $\alpha$-SMA mRNA expression significantly compared with EPO-treated animals. TGF- $\beta$ blockade alone did not influence $\alpha$-SMA mRNA expression (Figure 6b).

One of the most versatile processes involved in wound repair is proteolysis by matrix metalloproteinases, which is in turn inhibited by tissue-derived inhibitors, such as TIMPs. ${ }^{18}$ We examined, whether EPO regulates the expression of TIMP-1. We observed an $\sim 14$-fold statistically significant increase of TIMP-1 mRNA expression level in wounded skin compared with non-wounded skin (data not shown). However, treatment with EPO or anti-TGF- $\beta$ antibodies did not significantly influence TIMP-1 expression in wounded skin (data not shown).

\section{EPO Induces TGF- $\beta$ Signaling in Wounded Skin and Cultured Fibroblasts}

TGF- $\beta$ signal transduction depends on Smad family members such as Smad2, Smad3, and Smad4, whereas Smad7 inhibits the TGF- $\beta$ signaling pathway. Wounding in salinetreated animals caused a significant rise of Smad2 as well as
Smad7 mRNA expression (data not shown). EPO treatment enhanced mRNA expression levels of Smad2, -3 , and -4 , but did not enhance the expression of Smad7 (data not shown). Thus, EPO treatment increased the expression of several Smad family members known to mediate TGF- $\beta$ signaling.

Activation of TGF- $\beta$ signal transduction is characterized by phosphorylation of Smad2 and -3. EPO significantly enhanced phosphorylation of Smad2 and -3 in cultured primary fibroblasts and in L929 fibroblasts (Figures 7b and c). In MSC-P5 keratinocytes, however, a significant increase of Smad protein phosphorylation upon EPO exposure was not observed (Figure 7a). We also analyzed wound tissue samples immunohistochemically on day 3 and day 12 after wounding. EPO enhanced the phosphorylation of Smad 3 on day 3 after wounding (Figure 7d). Consistent with these data, Smad phosphorylation was also found markedly elevated on day 12 in wound tissue of EPO-treated animals when compared with wound tissue of control animals or EPO-treated animals, which received the anti-TGF- $\beta$ antibody (Figure 8).

\section{DISCUSSION}

The present study confirms the prohealing effect of EPO in skin repair, as shown previously by our and other groups. ${ }^{5,7-9}$ We extend the current knowledge providing evidence that EPO improves skin wound healing by activation of the 
a

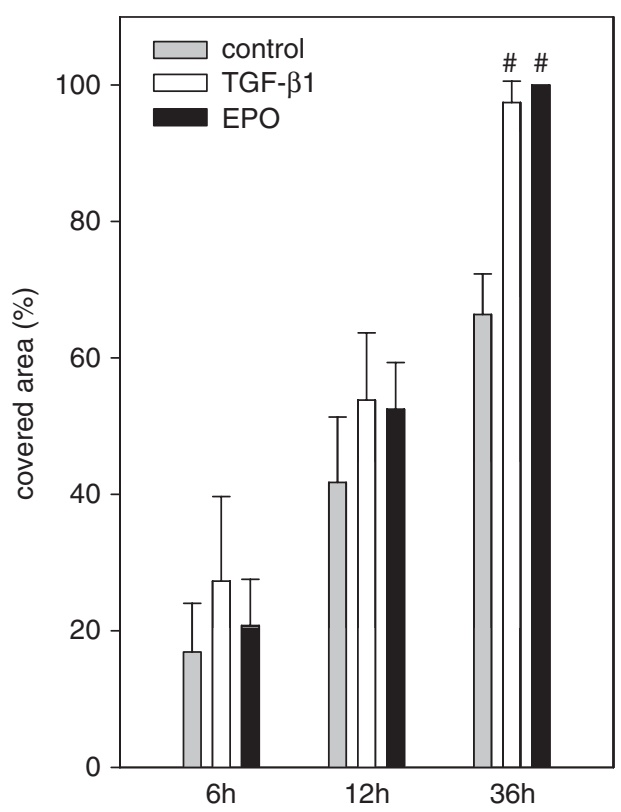

b
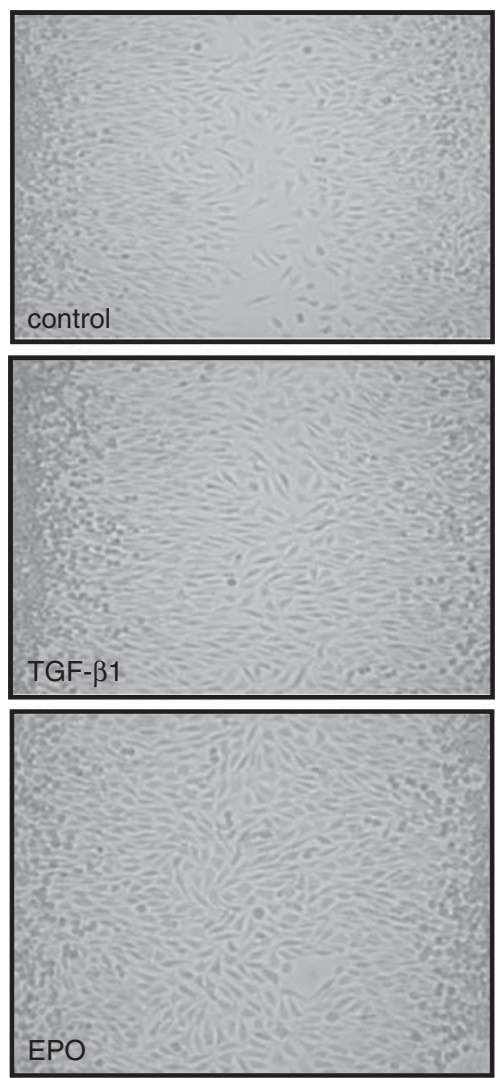

Figure 5 Assessment of cell migration in vitro. Quantitative assessment of migration reveals a significantly higher coverage of a $500-\mu \mathrm{m}$ gap with fibroblasts after $36 \mathrm{~h}$ of treatment with $10 \mathrm{ng} / \mathrm{ml} \mathrm{TGF-} \beta$ or $50 \mathrm{U} / \mathrm{ml} \mathrm{EPO} \mathrm{compared} \mathrm{with} \mathrm{control} \mathrm{(a).} \mathrm{Representative} \mathrm{images} \mathrm{of} \mathrm{L929} \mathrm{fibroblasts} \mathrm{at} 36 \mathrm{~h}$ (b). Values are given as mean values \pm s.d. ANOVA, followed by appropriate post hoc comparison test; $P<0.05$ vs control.

a

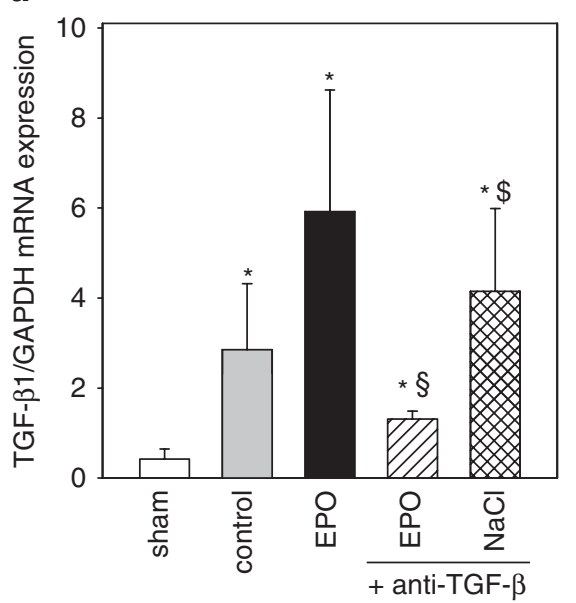

b

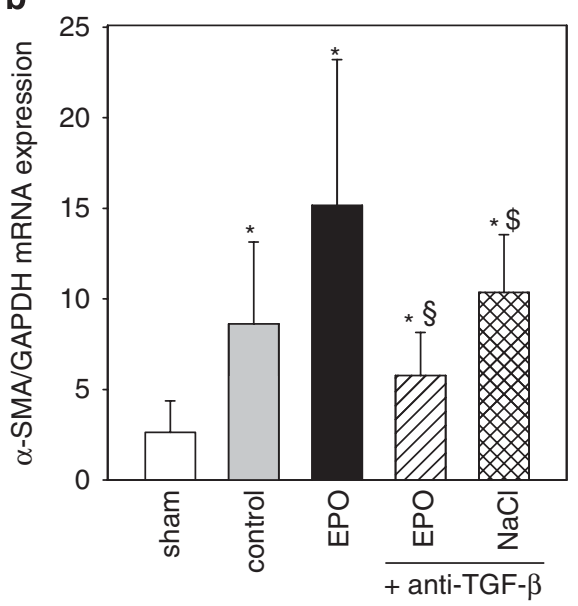

Figure 6 Quantitative real-time PCR analysis of TGF- $\beta 1$ (a), and $\alpha$-SMA (b) mRNA expression in skin tissue at day 12 post-wounding (control, EPO, $\mathrm{EPO}+$ anti-TGF- $\beta$ and $\mathrm{NaCl}+$ anti-TGF- $\beta$ group) or in non-wounded skin (sham group). Animals were treated i.p. with either saline (control; NaCl $0.9 \%$; $1 \mathrm{ml} / \mathrm{kg} \mathrm{bw})$, EPO at the day of wounding (EPO; $5.000 \mathrm{U} / \mathrm{kg} \mathrm{bw})$, EPO (5000 U/kg bw) and a pan-specific anti-TGF- $\beta$ antibody $(1 \mathrm{mg} / \mathrm{kg} \mathrm{bw})$, or NaCl $0.9 \%$ and a pan-specific anti-TGF- $\beta(1 \mathrm{mg} / \mathrm{kg} \mathrm{bw})$ at the day of wounding. Application of the anti-TGF- $\beta$ antibody (1 mg/kg bw i.p.) was repeated daily until day 12 (EPO + anti-TGF- $\beta ; \mathrm{NaCl}+$ anti-TGF- $\beta$ ). GAPDH served as reference gene for correcting the mRNA quantification of both target genes. Values are given as mean values \pm s.d. ANOVA, followed by appropriate post hoc comparison test; ${ }^{*} P<0.05$ vs sham; ${ }^{\S} P<0.05$ vs EPO; ${ }^{\$} P<0.05$ vs EPO + anti-TGF- $\beta$.

TGF- $\beta$ signaling pathway. This hypothesis is supported by our data, demonstrating that blockade of TGF- $\beta$ using an anti-TGF- $\beta$ antibody almost completely reversed the
EPO-associated salutary effects on skin repair. The proposed mechanism is further supported by data describing the activation of TGF- $\beta$ signaling in primary skin fibroblasts, 
a
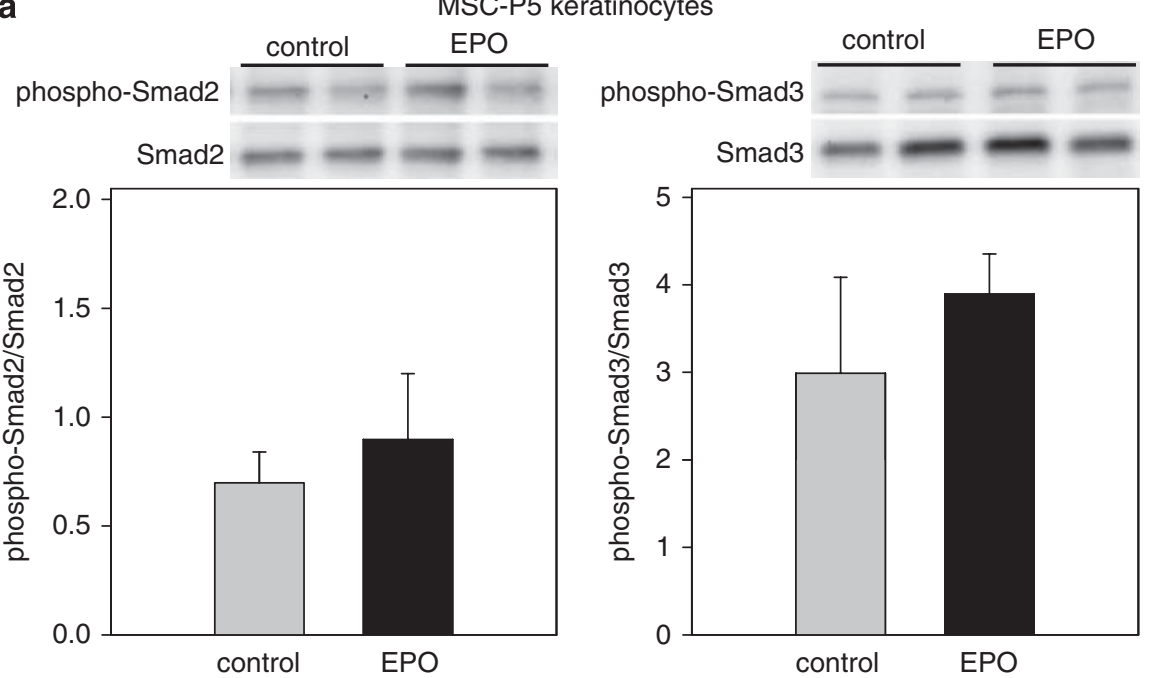

b
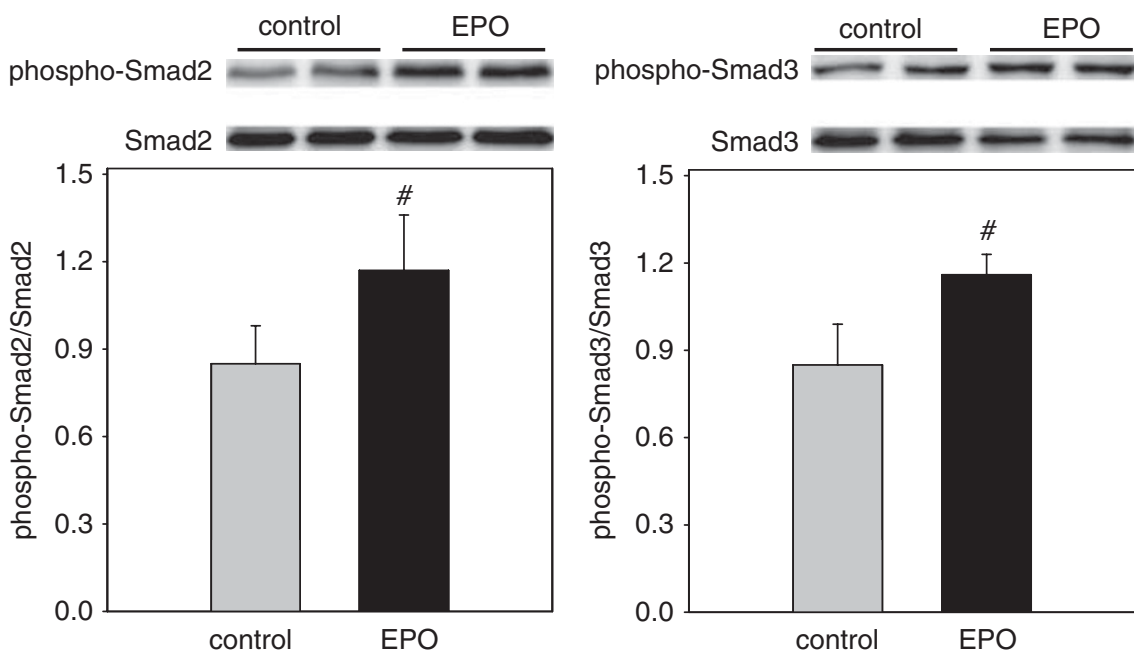

c

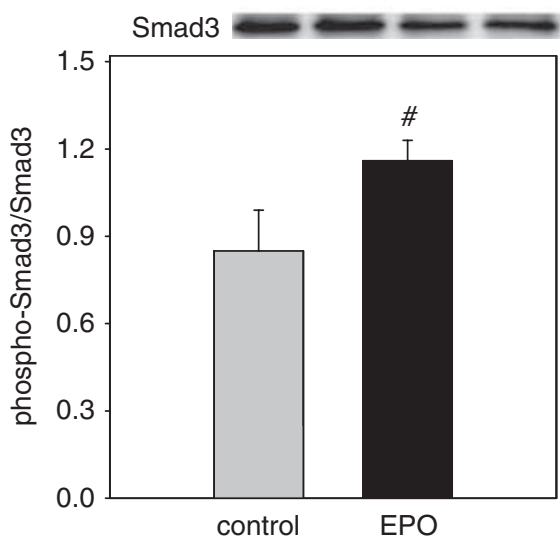

L929 fibroblasts
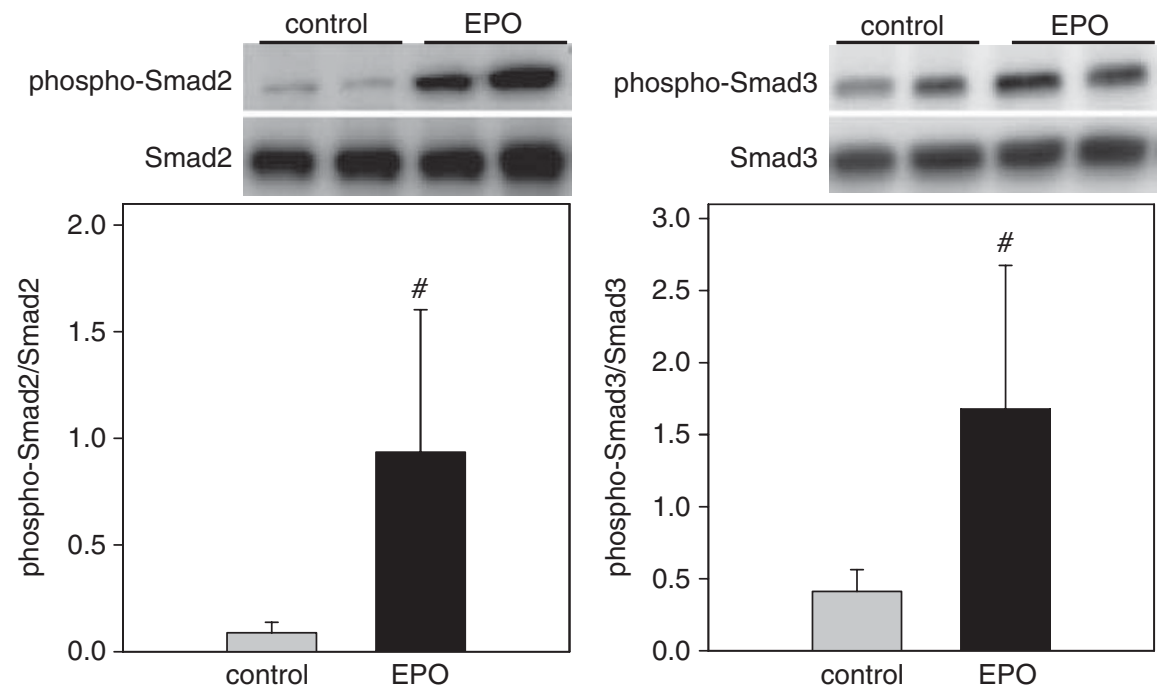

Figure 7 For caption see next page. 
L929 fibroblasts as well as in wounded skin tissue by EPO treatment.

A potential function of EPO and EPOR in uninjured skin is not well described, and little information is available about the expression of ligand and receptor in the skin. Both EPO and EPOR transcripts were detected in hair bulbs of hair follicles. ${ }^{19}$ In addition, EPO-like immunoreactivity was observed in hair follicle epithelium and in large blood vessels of human scalp. ${ }^{19}$ Moreover, in vitro studies demonstrated the expression of EPOR by melanocytes. ${ }^{20}$ In this study, we demonstrate that non-wounded and wounded skin of the mouse as well as murine primary fibroblasts and keratino- cytes express EPOR. The observed expression of EPOR in the skin supports the hypothesis that EPO acts locally to improve wound healing.

In line with the reports on the expression of TGF- $\beta$ and its receptors in skin wounds, ${ }^{21-24}$ we could detect increased TGF- $\beta 1$ expression after wounding. Though the regulative role of TGF- $\beta$ family members in wounded skin has been described in various experimental in vivo models, ${ }^{10,11}$ the exact mechanism of TGF- $\beta$ action is not completely understood. In our study, EPO markedly enhanced the phosphorylation of Smad3 in cultured fibroblasts and in wound tissue by EPO. These data support the assumption that EPO
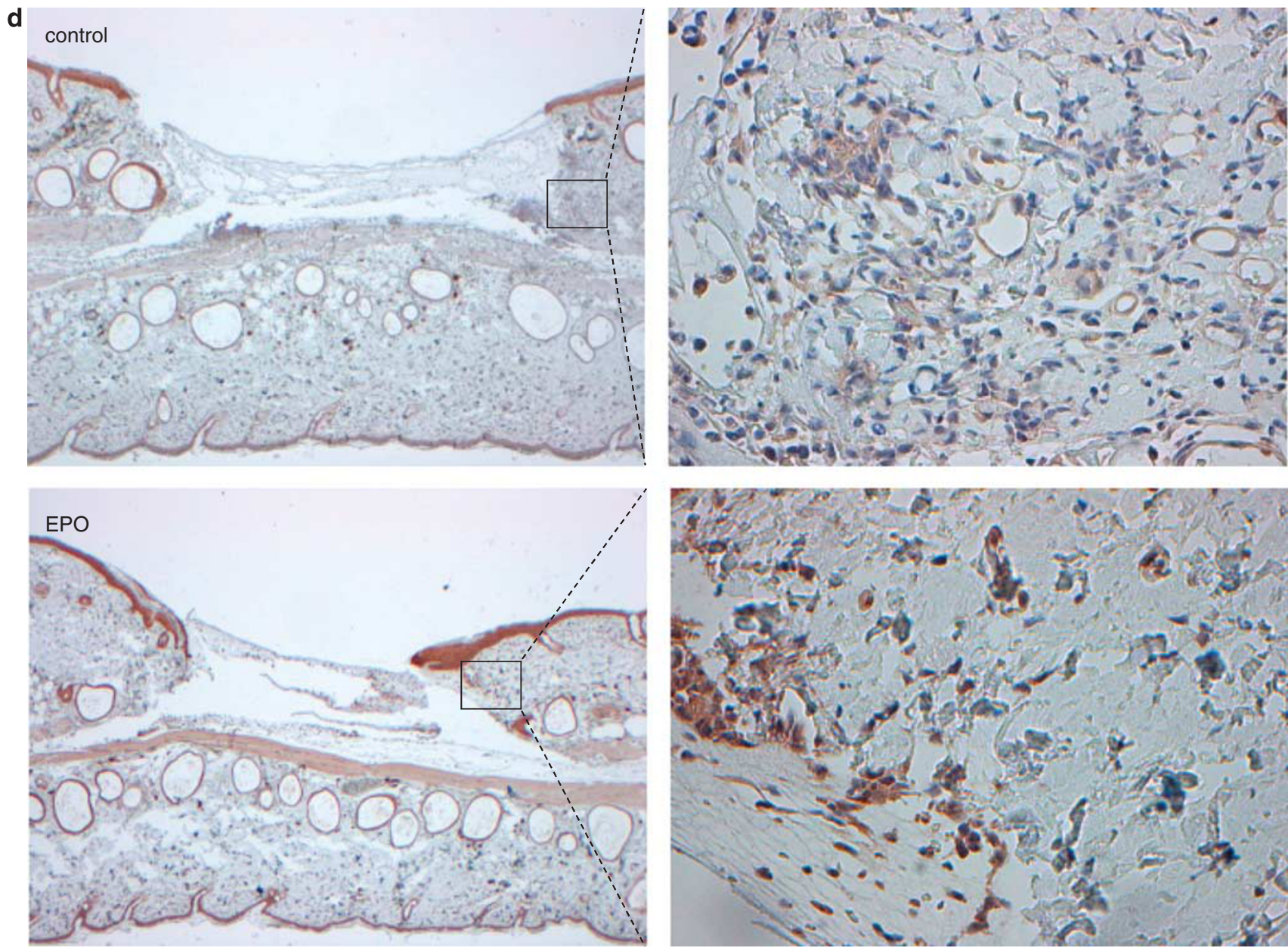

Figure 7 Analysis of Smad2 and -3 phosphorylation. Representative western blot analysis of phosphorylated Smad2 and Smad3 proteins in cultured keratinocytes (MSC-P5) (a), primary fibroblasts (b), and the fibroblast cell line L929 (c). Cells were treated with $50 \mathrm{U} / \mathrm{ml}$ EPO over a period of $24 \mathrm{~h}$. The data are represented in relation of phospho-Smad2-to-Smad2 and phospho-Smad3-to-Smad3 levels. Values are given as mean values \pm s.d. of three independent experiments per group. ANOVA, followed by appropriate post hoc comparison test; ${ }^{\#}<0.05$ vs control. Phospho-Smad3 immunohistochemistry in skin tissue at day 3 post-wounding (d). Animals were treated i.p. with either saline (control; $\mathrm{NaCl} 0.9 \% ; 1 \mathrm{ml} / \mathrm{kg}$ bw) or EPO at the day of wounding (EPO; $5.000 \mathrm{U} / \mathrm{kg} \mathrm{bw})$.

Figure 8 Representative images of Smad3 phosphorylation in wounded skin. Animals were treated i.p. with either saline (control; NaCl 0.9\%; $1 \mathrm{ml} / \mathrm{kg}$ bw), EPO at the day of wounding (EPO; $5.000 \mathrm{U} / \mathrm{kg} \mathrm{bw})$, EPO (5000 U/kg bw) and a pan-specific anti-TGF- $\beta$ antibody (1 mg/kg bw), or NaCl $0.9 \%$ and a pan-specific

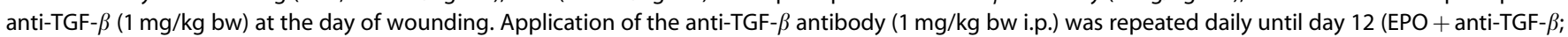
$\mathrm{NaCl}+$ anti-TGF- $\beta$ ). 

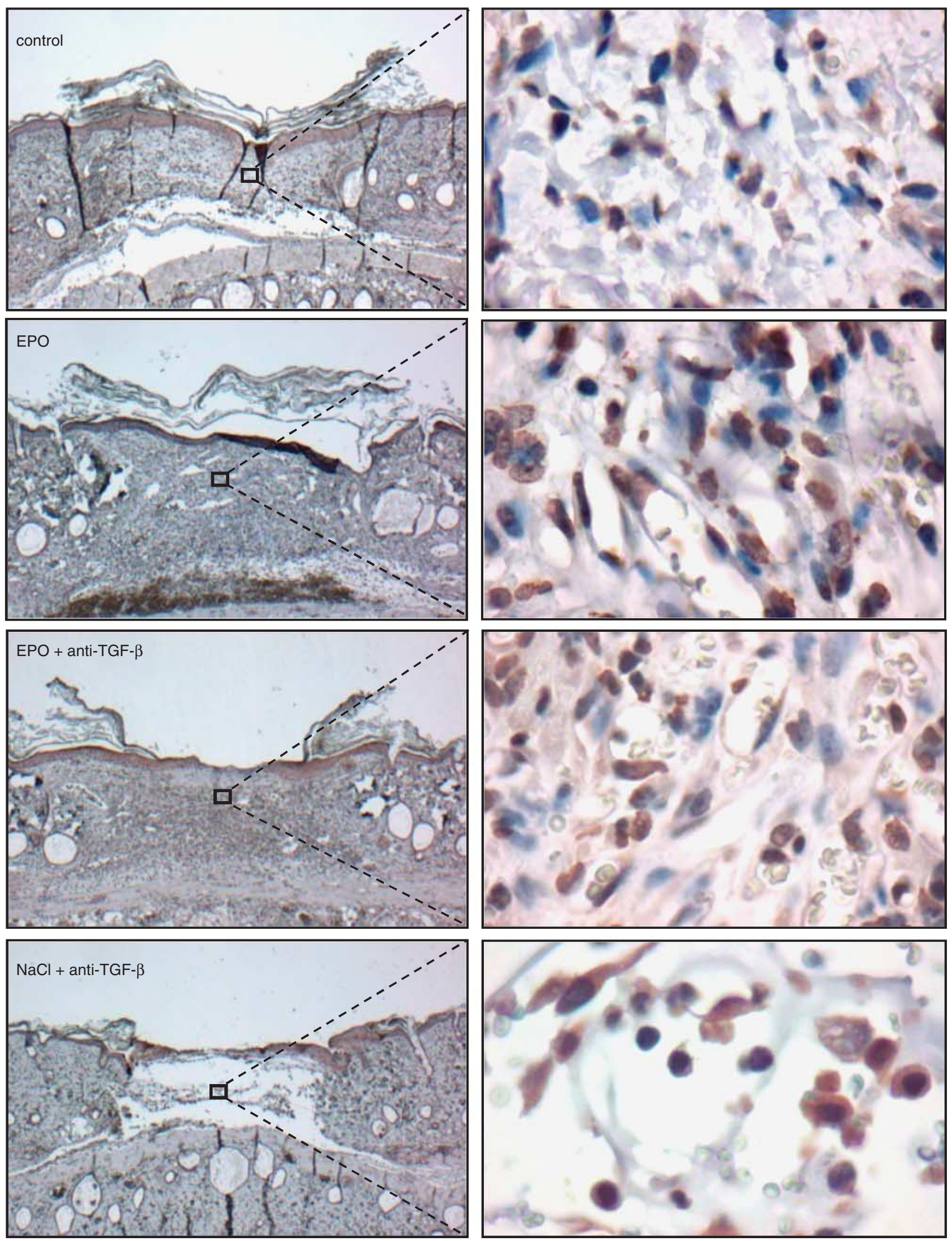
action involves the TGF- $\beta$ signaling pathway. Notably, we observed an inhibition of wound epithelialization by antiTGF- $\beta$ antibodies after EPO stimulation. After treatment with $\mathrm{NaCl}$, however, anti-TGF- $\beta$ antibodies did not exert a major inhibitory effect on wound epithelialization. This observation could be interpreted in that both TGF- $\beta$ and EPO signaling are simultaneously necessary to improve wound epithelialization. If TGF- $\beta$ signaling is necessary for wound healing in situations, where EPO is not administered, is highly controversial, since both a stimulatory function as well as an inhibitory function of TGF- $\beta$ signaling has been published in respect to wound healing. ${ }^{10,11}$

There is ample evidence for differential and complex regulation of Smads in skin pathophysiology. ${ }^{25-29}$ The complex role of Smads is further underlined by controversial data on the function of Smad3, as mice lacking Smad3 show accelerated wound healing, ${ }^{30}$ but altered mechanotransduction due to changes in ECM molecules. ${ }^{31}$ In the present study, EPO-induced acceleration of skin wound healing was associated with the upregulation of Smad2, -3, and -4 mRNA expression. In contrast to the agonistic Smads, Smad7 blocks TGF- $\beta$ signal transduction, in part, by preventing the interaction of Smad2/-3 with the activated TGF- $\beta$ type I receptor. ${ }^{32}$ Accordingly, in vivo blockade of Smad7 is reported to increase the rate of reepithelialization during wound healing in mice. ${ }^{33}$ In our study, EPO did not markedly change Smad7 mRNA expression, but the expression of Smad2, -3, and -4. This results in a dysbalance of Smads in favor of the agonistic Smad proteins. Although regulation of the mRNA level of distinct Smads may not automatically lead to changes in protein concentration or the activity of the TGF- $\beta$ signal transduction pathway, the observed dysbalance of Smads might nevertheless support the acceleration of wound healing upon EPO treatment.

Based on the fact that $\alpha$-SMA is a characteristic marker of myofibroblasts and its expression is induced by TGF$\beta 1,{ }^{17,34,35}$ we focused our mRNA analysis on these two genes. As the expression of TGF- $\beta 1$ mRNA was doubled upon application of EPO, we assume that the induction of $\alpha$-SMA expression found in the EPO group could reflect the direct effect of the increased TGF- $\beta 1$ production. This in turn is confirmed by our data showing that after EPO treatment TGF- $\beta$ blockade reduced expression of $\alpha$-SMA mRNA expression.

TGF- $\beta 1$ is one of the three TGF- $\beta$ family members, which have been shown to have a role in wound healing. ${ }^{11}$ Like TGF- $\beta 2$, TGF- $\beta 1$ has been described to be involved in recruiting inflammatory cells, stimulating granulation, inducing angiogenesis, influencing reepithelialization, and stimulating collagen production during wound healing of the skin. ${ }^{11}$ The third family member TGF- $\beta 3$ also promotes wound healing by recruiting inflammatory cells, but is a potent inhibitor of DNA synthesis in keratinocytes. ${ }^{11}$ In contrast to TGF- $\beta 1$ and TGF- $\beta 2$, TGF- $\beta 3$ has been reported to inhibit scarring. ${ }^{11}$ Thus, TGF- $\beta 3$ can have dis- tinct functions, when compared with TGF- $\beta 1$ and TGF- $\beta 2$. We demonstrated that EPO induces TGF- $\beta 1$ expression in vivo, and that TGF- $\beta 1$ and EPO stimulate the migration of fibroblasts in vitro. This suggests that EPO-accelerated wound healing may involve TGF- $\beta 1$. This hypothesis is consistent with studies on $\beta 3$-integrin-deficient mice, which show accelerated reepithelialization by inducing TGF- $\beta 1$ expression. ${ }^{36}$ However, all three TGF- $\beta$ family members have been reported to stimulate wound healing. ${ }^{11}$ Thus, we cannot exclude that the observed inhibition of wound healing by application of a pan-specific antibody to TGF- $\beta$ might also be partially mediated by inhibition of TGF- $\beta 2$ or TGF- $\beta 3$.

In summary, our data support the hypothesis that the prohealing effect of EPO on skin wounds involves the TGF- $\beta /$ Smad signaling pathway. The blockade of TGF- $\beta$ showing an almost complete reversion of the EPO-associated salutary effects on wound repair underlines this conclusion. The present study contributes to a better understanding of the non-hematopoietic biology of EPO.

\section{ACKNOWLEDGEMENTS}

The authors cordially thank the technicians Berit Blendow, Doris Butzlaff, Dorothea Frenz, and Maren Nerowski for excellent assistance. This study is supported by a grant from the Deutsche Forschungsgemeinschaft (Vo 450/10-1; Bonn, Bad Godesberg, Germany).

\section{DISCLOSURE/CONFLICT OF INTEREST}

The authors declare no conflict of interest.

1. Jelkmann W. Biology of erythropoietin. Clin Invest 1994;72:S3-S10.

2. Arcasoy MO. The non-haematopoietic biological effects of erythropoietin. Br J Haematol 2008;141:14-31.

3. Youssoufian $\mathrm{H}$, Longmore $\mathrm{G}$, Neumann $\mathrm{D}$, et al. Structure, function, and activation of the erythropoietin receptor. Blood 1993;81:2223-2236.

4. Ogilvie $M, Y u X$, Nicolas-Metral $V$, et al. Erythropoietin stimulates proliferation and interferes with differentiation of myoblasts. J Biol Chem 2000;275:39754-39761.

5. Galeano M, Altavilla D, Bitto A, et al. Recombinant human erythropoietin improves angiogenesis and wound healing in experimental burn wounds. Crit Care Med 2006;34:1139-1146.

6. Brines $M$, Cerami A. Erythropoietin-mediated tissue protection: reducing collateral damage from the primary injury response. J Intern Med 2008;264:405-432.

7. Haroon $Z A$, Amin $K$, Jiang $X$, et al. A novel role for erythropoietin during fibrin-induced wound-healing response. Am J Pathol 2003;163: 993-1000.

8. Sorg $H$, Krueger $C$, Schulz $T$, et al. Effects of erythropoietin in skin wound healing are dose related. FASEB J 2009;23:3049-3058.

9. Hamed S, Ullmann $\mathrm{Y}$, Masoud $\mathrm{M}$, et al. Topical erythropoietin promotes wound repair in diabetic rats. J Invest Dermatol 2010;130:287-294.

10. Werner S, Grose R. Regulation of wound healing by growth factors and cytokines. Physiol Rev 2003;83:835-870.

11. Barrientos S, Stojadinovic O, Golinko MS, et al. Growth factors and cytokines in wound healing. Wound Repair Regen 2008;16:585-601.

12. Li J, Zhang YP, Kirsner RS. Angiogenesis in wound repair: angiogenic growth factors and the extracellular matrix. Microsc Res Tech 2003; 60:107-114.

13. Ashcroft GS, Roberts $A B$. Loss of Smad3 modulates wound healing. Cytokine Growth Factor Rev 2000;11:125-131.

14. Derynck $\mathrm{R}$, Zhang $\mathrm{Y}$, Feng $\mathrm{XH}$. Smads: transcriptional activators of TGF-beta responses. Cell 1998;95:737-740.

15. Massagué J. TGF-beta signal transduction. Annu Rev Biochem 1998;67:753-791. 
16. Hayashi $\mathrm{H}$, Abdollah $\mathrm{S}$, Oiu $\mathrm{Y}$, et al. The MAD-related protein Smad7 associates with the TGFbeta receptor and functions as an antagonist of TGFbeta signaling. Cell 1997;89:1165-1173.

17. Hinz B. Formation and function of the myofibroblast during tissue repair. J Invest Dermatol 2007;127:526-537.

18. Matrisian LM. The matrix-degrading metalloproteinases. Bioessays 1992;14:455-463.

19. Bodó E, Kromminga A, Funk W, et al. Human hair follicles are an extrarenal source and a nonhematopoietic target of erythropoietin. FASEB J 2007;21:3346-3354.

20. Selzer E, Wacheck V, Kodym R, et al. Erythropoietin receptor expression in human melanoma cells. Melanoma Res 2000;10:421-426.

21. Gold LI, Sung JJ, Siebert JW, et al. Type I (RI) and type II (RII) receptors for transforming growth factor-beta isoforms are expressed subsequent to transforming growth factor-beta ligands during excisional wound repair. Am J Pathol 1997;150:209-222.

22. O'Kane S, Ferguson MW. Transforming growth factor $\beta$ s and wound healing. Int J Biochem Cell Biol 1997;29:63-78.

23. Schmid P, Cox D, Bilbe G, et al. TGF-beta s and TGF-beta type II receptor in human epidermis: differential expression in acute and chronic skin wounds. J Pathol 1993;171:191-197.

24. Schmid $P$, Itin $P$, Cherry $G$, et al. Enhanced expression of transforming growth factor-beta type I and type II receptors in wound granulation tissue and hypertrophic scar. Am J Pathol 1998;152: 485-493.

25. Cutroneo KR. TGF-beta-induced fibrosis and SMAD signaling: oligo decoys as natural therapeutics for inhibition of tissue fibrosis and scarring. Wound Repair Regen 2007;1:S54-S60.

26. $\mathrm{Yu} \mathrm{H}$, Mrowietz U, Seifert O. Downregulation of SMAD2, 4 and 6 mRNA and TGFbeta receptor I mRNA in lesional and non-lesional psoriatic skin. Acta Derm Venereol 2009;89:351-356.
27. Dong $C$, Zhu S, Wang T, et al. Deficient Smad7 expression: a putative molecular defect in scleroderma. Proc Natl Acad Sci USA 2002;99:3908-3913.

28. Han $\mathrm{KH}, \mathrm{Choi} \mathrm{HR}$, Won $\mathrm{CH}$, et al. Alteration of the TGF-beta/SMAD pathway in intrinsically and UV-induced skin aging. Mech Ageing Dev 2005; 126:560-567.

29. Reisdorf P, Lawrence DA, Sivan V, et al. Alteration of transforming growth factor-beta1 response involves down-regulation of Smad3 signaling in myofibroblasts from skin fibrosis. Am J Pathol 2001;159:263-272.

30. Ashcroft GS, Yang $X$, Glick AB, et al. Mice lacking Smad3 show accelerated wound healing and an impaired local inflammatory response. Nat Cell Biol 1999;1:260-266.

31. Arany PR, Flanders KC, Kobayashi T, et al. Smad3 deficiency alters key structural elements of the extracellular matrix and mechanotransduction of wound closure. Proc Natl Acad Sci USA 2006;103:9250-9255.

32. Nakao A, Afrakhte M, Morén A, et al. Identification of Smad7, a TGFbetainducible antagonist of TGF-beta signalling. Nature 1997;389:631-635.

33. Reynolds LE, Conti FJ, Silva $\mathrm{R}$, et al. alpha3beta1 integrin-controlled Smad7 regulates reepithelialization during wound healing in mice. J Clin Invest 2008;118:965-974.

34. Desmoulière $A$, Geinoz A, Gabbiani $F$, et al. Transforming growth factor-beta 1 induces $\alpha$-smooth muscle actin expression in granulation tissue myofibroblasts and in quiescent and growing cultured fibroblasts. J Cell Biol 1993;122:103-111.

35. Rønnov-Jessen $L$, Petersen OW. Induction of $\alpha$-smooth muscle actin by transforming growth factor-beta 1 in quiescent human breast gland fibroblasts. Implications for myofibroblast generation in breast neoplasia. Lab Invest 1993;68:696-707.

36. Reynolds LE, Conti FJ, Lucas M, et al. Accelerated re-epithelialization in beta3-integrin-deficient-mice is associated with enhanced TGF-beta1 signaling. Nat Med 2005;11:167-174. 